\title{
Digital Marketing Implementation Effectiveness Analysis in Improving the Marketing Performance of Small and Medium Enterprises Managed by LINKS USU
}

\author{
Ikhsan Al Zuhri ${ }^{1}$, Sukaria Sinulingga ${ }^{2}$, Iskandarini ${ }^{3}$ \\ ${ }^{1,2,3}$ Master of Management Study Program on Postgraduate School of University of Sumatera Utara Medan, \\ Indonesia.
}

\begin{abstract}
Marketing performance is a measure of achievement and marketing process activity as a whole from a company. Marketing performance can also be seen as a concept that is used by a product by a company. There are many factors that affect the marketing performance, among them is digital marketing. This research is a descriptive correlational analysis with quantitative research approach. This method is intended to examine to what extent the variation of one factor in relation to other variation of another factor (Rakhmat, 2004). Correlation Method is intended to analyze the effectiveness between digital marketing implementation towards marketing performance of Small to Medium Enterprises (SME) in LINKS USU. The research's populations are every Small to Medium Enterprises owner in Medan City Managed by Innovation and Business Technology Incubation Department North Sumatra University that have already used digital marketing technology for the past year.
\end{abstract}

Keywords: Effectiveness, Digital Marketing, Marketing Performance, SME.

\section{BACKGROUND}

The fast advancement of technology, digital world and internet is heavily affecting the marketing world. The world's marketing trends have shifted from the conventional way (offline) to digital (online). This digital marketing strategy is more prospective because it allows the potential customers to get any kind of information about a product and doing transaction via internet.

Indonesian people's shift of behavior is also shown via survey that was held by shopback Indonesia in 2018, it predicted that there will be a change such as 1) shopping behavior pattern shifted to online, 2) Same day delivery service will be the main option, 3) E-commerce application users open online shops, 4) Online shopping will be preferred because there are many promos offered, 5) Digital wallet growth will be significant, 6) Online ticket selling will be increasing and will be a new hope for SME to grow and develop.

But this chance is not followed by the majority of company's change of perspective and the people who involved in the digital marketing. Big or small companies, or even individual are starting to use digital platform and social media as a way to promote or closing the distance to the consumer, but unfortunately the interaction is still very limited. The marketing utilization via digital media (digital marketing) is still not maximum if compared to the drastic growth of internet user. According to McKinsey's research there is just 30\% SME owners in Indonesia that use the digital instrument to develop their businesses (Supriadi, 
http://www.marketing.co.id, 2016). Seeing this, researchers conclude that the digital marketing in Indonesia is still massive.

Business competition that is getting complex is forcing SME to be more creative to maintain their business' existence. SME has to be able to try to fulfill the people's need that demands fast services for their needs. One of the ways to realize the speed in service is to integrate company's information system to be more effective and efficient. When a company become effective and efficient, then it will improve its competitiveness in business market, therefore the company will still be exist (Mudiantono, 2015). But, good at competition is not the main goal, SME owners have to improve themselves in every aspect to maintain and improve the marketing performance (Mulyani, 2015).

\section{LITERATURE REVIEW DIGITAL MARKETING}

Digital marketing according to Chaffey (2002) is a digital technology application that shapes online channel to the market (website, e-mail, database, digital TV and through other various new innovation including blog, feed, podcast, and social media) that gives contribution to marketing activity, that has goals to get profit and maintain consumer (in a multichannel buying process and consumer life cycle), by recognizing how important the digital technology and improving the planned approach to raise consumer's awareness (towards the company, behavior, value and loyalty booster to its product's brand), and then sent the message via communication activity and online based service that is integrated and focused to fulfill specific customer needs.

Dimensions of digital marketing from the promotion standpoint according to Chaffey \& Ellis Chadwick (2012), are:

1. Search Engine Marketing (SEM)

2. Online Public Relation

3. Online Partnership

4. Online Advertising

5. Social Media Marketing

\section{Email Marketing}

\section{Marketing Performance}

Marketing performance is a measure of achievement and marketing process activity as a whole from a company. Marketing performance can also be seen as a concept that is used by a product by a company. According to Riani and co (2015) marketing performance is an achievement produced by effects from various roles that have functions in an organization; marketing performance is a generally important element from company's performance, because a company's performance can also be seen from its marketing performances so far.

Marketing performance dimension according to Rasyidi (2015) are:

1. Sales Volume

2. Rate of Sales

3. Sales Area Coverage

\section{Effectiveness}

According Rangkuti and Freddy, marketing effectiveness is to what extent a company reach its target that has been planned before. It can be said that if a marketing can be executed well according to company's plan or target, therefore it can be said that the marketing is effective.

Marketing effectiveness is the marketer's quality to optimize their effort and reach the best short and long term result. Marketing effectiveness is related to the Return on Investment Marketing (ROMI) and ROI that help to show the correlation between cost and result in the form of profit or direction.

\section{RESEARCH METHOD}

Theoretical framework of a research is built upon logical construction from past research documents in a similar field so it is integrated as one and unified while also paying attention to constraints and problems in relation to the undergoing situation (Sinulingga, 2011). This thought framework is extracted by the combination of variables that can be used to formulate hypothesis. 
Ikhsan Al Zuhri et.al. Digital marketing implementation effectiveness analysis in improving the marketing performance of small and medium enterprises managed by LINKS USU.

This research is an evaluation towards digital marketing implementation to increase the income of SEM in Medan City managed by Innovation and Business
Technology Incubation Department North Sumatra University, therefore the research flow can be showed as below:

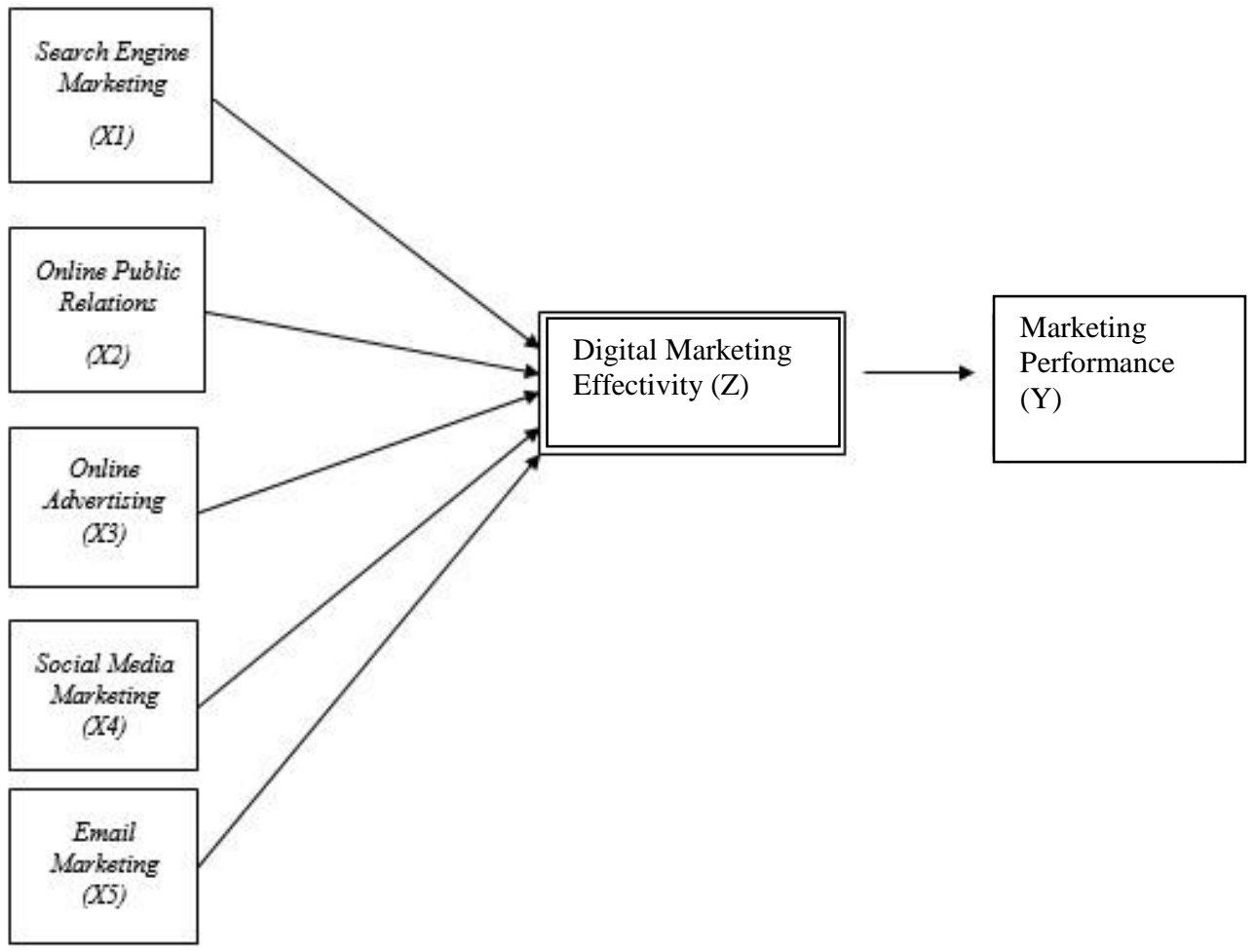

Figure 1. Conceptual Framework

\section{Hypothesis}

1. There is a positive relation between digital marketing implementation and marketing performance of SME managed by LINKS USU.

2. There is a positive relation between digital marketing implementation effectiveness towards the marketing performance of SME managed by LINKS USU.

\section{RESEARCH METHODS}

This research is an analytical descriptive correlational with quantitative research approach. This method is intended to find out to what extent a variation of one factor correlates with another factor's variation (Rakhmat, 2004). Correlation method is intended to analyze the effectiveness between digital marketing implementation towards marketing performance of SME in LINKS USU.

\section{Population}

Population is a generalized area that is consisted of: objects/subjects that have distinctive qualities and characteristics that have been set by the researchers to study and then drawn into conclusion (Sugiyono, 2012). Target Population that has been set by the researchers is every SME owners in Medan City managed by Innovation and Business Technology Incubation Department North Sumatra University that has been using digital marketing technology for the past year.

\section{Sample}

Sample is a data collection whereas only some of the population are taken and used to determine the characteristics and features desired from a population (Siregar, 2013). The sampling technique in this research is using non probability sampling with purposive sampling type. Non probability sampling is whenever every 
elements in the population does not have the same chance to be picked as a sample (Siregar, 2013).

Purposive sampling is a method of determining respondent to be made as a sample based on certain criteria (Siregar, 2013). Sampling determination criteria in this research are Respondents that live in Medan City, respondents have businesses and considered able to answer the questionnaire objectively and respondents that have businesses and have used digital marketing for the past year or more.

\section{Operational Variable Definition}

1. Digital Marketing (X)

a. Search Engine Marketing (X1)

b. Online Public Relation (X2)

c. Online Advertising (X3)

d. Social Media Marketing (X4)

e. E-mail Marketing (X5)

2. Effectiveness $(Z)$

a. Business Outcomes

b. Communication Outcomes

3. Marketing Performance(Y)

a. Sales Volume

b. Marketing Area Coverage

\section{RESULT AND DISCUSSION}

\section{Hypothetical Test Result}

\section{Determination Coefficient Test Result}

Determination Coefficient Test showed that how much percentage $(\%)$ of affection that has been given by digital marketing variable and effectiveness variable simultaneously towards marketing performance variable with the following result:

Table 1: Determination Coefficient Test Result $\left(R^{\wedge} 2\right)$

$$
\text { Model Summary }
$$

\begin{tabular}{ll|r|r|r} 
Model & R & R Square & \multicolumn{1}{c}{$\begin{array}{c}\text { Adjusted R } \\
\text { Square }\end{array}$} & $\begin{array}{c}\text { Std. Error of } \\
\text { the Estimate }\end{array}$ \\
\hline 1 & $.587^{\text {a }}$ &, 344 &, 324 & 2,485 \\
\hline
\end{tabular}

a. Predictors: (Constant), Efektivitas, Digital Marketing

According to table 1 SPSS output "model summary", it was known that the determination coefficient or $\mathrm{R}$ Square is 0.344 . R Square value 0,344 came from the squaring of Correlation Coefficient or " $\mathrm{R}$ ", which was $0,587 \times 0,587=0,344$. The value of Determination Coefficient ( $\mathrm{R}$ Square) is 0,344 or equal to $34,4 \%$. That number means that digital marketing variable and effectiveness variable simultaneously affected the marketing performance variable as big as $34,4 \%$ while the rest $65,5 \%$ has affected by other variables outside of the Correlation equation or unresearched variable.

\section{Correlation between Search Engines Marketing Towards Digital Marketing}

Analysis result showed that search engine marketing has a very strong correlation towards digital marketing. This is indicated by value $r_{\text {hituna }}(0,931)>$ from $r_{\text {tabel }}<0,05$, this means that the stronger the search engine marketing, the stronger the digital marketing of SME.

Search engine usage will make the SME owners more focused to the marketing target. About the marketing target, the SME owners will be specific and relevant in line with the website or products. The impact is that the SME owners will get better prospective customers. Other than that, the visitor's potential to make buy will be higher. In which, the profit margin of SME owners will be much higher than before using search engine marketing.

\section{Correlation between Online Public Relations towards Digital Marketing}

Analysis result showed that online public relation has a very strong correlation towards digital marketing. This is indicated by value $r_{\text {hitung }}(0,919)>$ from $r_{\text {tabel }}<$ 0,05 , this means that the stronger the online public relation, the stronger the digital marketing of SME.

Online public relation is an important part for the company to develop brand or create relationship with the community. These days, online public relation is done via platforms in the internet and can be used to create opportunities, and also open the way to get the business owners' campaign target. 
In this digital era, website is the main platform to do online public relation. Business owners have to ensure that the website being used is showing professional and fresh design, by using quality images or photos, and showing clear brand identity and using contents and inviting the customers to act. Online public relation usage and careful marketing plan will surely grow the traffic to the business owners' website.

\section{Correlation between Online Advertising towards Digital Marketing}

Analysis result showed that online advertising has a strong correlation towards digital marketing. It is indicated by value $r_{\text {hituna }}(0,619)>$ from $r_{\text {tabel }}<0,05$, this means that the stronger the online advertising, the stronger the digital marketing of SME.

Online advertising is divided into several forms, some of which are video advertising, self service advertising, and contextual advertising. According to Kotler and Amstrong (1997:80), one of the advantages of online advertising is that the internet is a quickly grown media, so it can reach its narrow target audience, most needs short time frame to create advertisement via web, with a relatively cheap price. While its drawbacks is that, today not every prospective customers have access to internet, hard to measure its effectiveness and its investment return and lastly the advertisement exposure relies on "click via" title in the advertisement.

Business owners need to understand who involved in the decision to buy and the roles played by everyone. Every decision taken by customers to choose and buy a product is a collection of a number of decisions, and it has to be studied by a business owner through whole buying decision planning that is used as a consideration for the customer to determine the decision to buy.

Basically, today's advertisements have influenced every people's daily lives and affect many buyings. Customers saw advertisements to get information and entertainment values (Lamb dan Hair, 2001:204). Advertisements is a part of promotion mix, especially the advertisement that uses online media these days that have gotten quite high attention from the customers, giving information about the advantages that a product has through sound aspect, motion, music, and images, and also reach to almost every level of society, knowing these days technology is growing from time to time.

\section{Correlation between Social Media Marketing Towards Digital Marketing}

Analysis result showed that social media marketing has a very strong correlation towards digital marketing. This is indicated by value $r_{\text {hitung }}(0,910)>$ from $r_{\text {tabel }}<0,05$, this means that the stronger the social media marketing, the stronger the digital marketing of SME.

According to the research data, SME owners managed by LINKS USU utilized social media marketing especially the Whatsapp application to sell their products or services. SME owners managed by LINKS USU utilized Whatsapp's features as a strategy to develop their businesses. Whatsapp is quite effective as marketing and promotional media. Through Whatsapp, SME owners can promote and sell their products or services with the video feature, it is used well enough to create their customers' interest to their products.

Text, picture, or GIF contents can be utilized in the Whatsapp application. It could create an interesting message for the customers to see. Text format in Whatsapp can be made into several forms, and given emphasis in some words. With this, Whatsapp can raise the curiosity of prospective customer and subconsciously they will be connected to the products or services offered.

At the beginning of COVID-19 pandemic, LINKS USU had initiated to build a place for SMEs they've managed to sell in a Whatsapp group called "Bazar Online LINKS USU", through that 
Whatsapp group the business owners could find out how much of the group's member have seen their messages.

Through the Whatsapp group provided by LINKS USU, the business owners managed by LINKS USU could increase their product sales, and grow their business. Utilization of Whatsapp also flawlessly increases the owners' delivery system. The customers could share their location via Whatsapp, and gave on point coordinates. Coordinate or share location is really helping the SME managed by LINKS USU to do deliveries faster by choosing shortest routes to optimize the delivery cost, therefore the delivery cost is less than the bought product.

Through Whatsapp SME owners managed by LINKS USU can also feel closer with the customers. The customers can effectively communicate with the business owners via chatting. Because of that, the SME can utilize this chatting to increase the service for the customers. The customers and prospective customers could order directly and fast.

However, Whatsapp usage as a means of digital marketing also has its drawbacks. First of all, this app didn't provide advertisement feature to do promotion. To get prospective customers to contact via Whatsapp, it needs synchronization from social media such as Instagram, Facebook, and TikTok. The SME owners can give the links that connects to the Whatsapp. Other than that, there are still many SME owners managed by LINKS USU that used their own private numbers to sell their products and services.

\section{Correlation Between E-mail Marketing Towards Digital Marketing}

Analysis result showed that E-mail marketing has a very strong correlation towards digital marketing. It is indicated by value $r_{\text {hitung }}(0,908)>$ from $r_{\text {tabel }}<0,05$, that means the stronger the E-mail marketing, the stronger the SME's digital marketing.
E-mail Marketing, compared to other marketing methods, it is a little bit traditional. This type of marketing is different to social media marketing that enables the user to directly comment the given product. But, by the building long term relation with customers' standpoint, this technique can be appropriate. Through this technique, business owners can steal the customers' heart and make them more loyal. If the customers are loyal, then they will not just read the E-mail that have been sent to them about a product. But they will patiently wait for E-mails about new products.

E-mail marketing becomes important because they have the potential to acquire new customer that is more massive compared to the others. According to WBR Digital, the success rate of new customer acquisition in this type is up to $81 \%$, much higher than via social media marketing that only reaches $51 \%$.

The last thing that makes this type important is the cheap cost. According the Direct Marketing Association study, if a $1 \$$ worth E-mail is sent, there is a potential to gain profit up to $40 \$$.

\section{Correlation Between Digital Marketing Towards Marketing Performance}

Analysis result showed that digital marketing has a fairly strong correlation towards marketing performance. This can be indicated by value rhitung $(0,495)>$ from rtabel $<0,05$, this means the stronger the digital marketing, the stronger the SME marketing performance

According to the research result, digital marketing has direct correlation, positive and significant towards marketing performance, this is in line with digital marketing that had been done by SME owners where through utilization of IT, online can reach even far away consumers, that means there is a widening of market share that caused the increase of customers. Another thing is a utilization of online application can also be used as a promotion media by SME owners themselves, so it 
opened infinite customer opportunities. Increase of competitiveness is also happening where the SME owners will be struggling to ensure their qualities in order to maintain customers.

Utilization of digital marketing by SME owners also showed that there is a difference between income of SME that used online IT and SME that still does not used it, so it can be said that digital marketing utilization can be used to boost SME sales and also be an alternative transaction media to maintain and improve the business' sustainability in Covid-19 pandemic.

\section{Correlation Between Effectiveness towards Marketing Performance}

Analysis result showed that effectiveness has a direct connection, positive and significant towards marketing performance. This is indicated by value

$r_{\text {hitung }}(0,558)>$ from $r_{\text {tabel }}<0,05$, this means the stronger the effectiveness, the stronger the marketing performance of SME.

To every indicator that shaped the variable $\mathrm{Y}$ (performance) that consisted of 1) Increase of sales ; 2) Advertisement cost reduction ; 3) Increasing the exchange of information with consumer ; 4) Help SME to have strong position ; 5) Help to give price transparency towards consumer ; 6) Create brand awareness ; 7) Increase the consumer's loyalty.

According to statistical test, it showed that there are impacts of technology usage toward marketing performance especially in the Covid-19 pandemic. For culinary entrepreneurs, technology usage can decrease the cost by shifting it to another party. One of the utilization of online technology is the use of online application services via smartphone. When SME owners choose to do transactions online, then the huge delivery cost will be given to another party. Business owners do not have to prepare for big budget to develop their own delivery order, because the online based application can be a really helping alternative solution. Business owners can have delivery order without preparing their own armada. Therefore, business owners do not have to pay for their own couriers. Business owners do not even have to have their own physical shop for doing business. Utilization of online technology can also be used to increase the market share, and it is one of the alternatives to increase customers in Covid19 pandemic, because old customers will choose not to do direct transaction to maintain health protocol.

\section{CONCLUSION}

Factors that related to digital marketing are search engine marketing, online public relationship, online advertising, social media marketing, and email marketing. From this research it is found that social media marketing is the most correlated factor in improving the SME LINKS USU marketing performance

Digital Marketing effectiveness will be able to strengthen SME to improve the marketing performance, especially in the present state of uncertainty because of Covid-19 pandemic. Utilization of online technology such as online Go-food/Grabfood, Utilization of social media such as Instagram and Facebook will finally be an alternative to micro enterprises to endure in the pandemic of Covid-19. This application is not only shorten the distance between the customers and outlets but also be a way to keep gaining income from businesses.

\section{Acknowledgement: None}

\section{Conflict of Interest: None}

\section{Source of Funding: None}

\section{REFERENCES}

1. Ari Susanti, Budi Istiyanto, dan Muhammad Jalari (2020). "SMEs Strategy at Covid-19 Pandemic". KANGMAS: Karya Ilmiah Pengabdian Masyarakat, Vol.1 No.2. eISSN: 2722-2004. 
2. Andi Amri (2020). "Dampak Covid-19 Terhadap UKM di Indonesia". Jurnal Brand, Volume 2 No. 1. e-ISSN: 2715-4920

3. [BPS] Badan Pusat Statistik. 2017. Perkembangan Data Usaha Mikro, Kecil, Menengah (UMKM) dan Usaha Besar (UB) Tahun 2016 - 2017. Jakarta: BPS.

4. Chaffey, D. (2012). E-Business \& Ecommerce Management: Strategy, Implementation and Practice (5th ed.). Harlow, Essex: Financial Times Prentice Hall.

5. Ghozali, Imam. (2010). Analisis Multivariaet dengan Program SPSS. Semarang:Undip

6. Ghozali, Imam. (2013). Aplikasi Analisis Multivariete Dengan Program IBM

7. SPSS 23, Edisi 8. Semarang : Penerbit Undip

8. Hanum, A. N., \& Sinarasri, A. (2017). Analisis faktor-faktor yang mempengaruhi adopsi e commerce dan pengaruhnya terhadap kinerja umkm (studi kasus umkm di wilayah kota semarang). Maksimum, Vol. 1(No. 1), 1-15.

9. Helmalia, H., \& Afrinawati, A. (2018). Pengaruh E-Commerce Terhadap Peningkatan Pendapatan Usaha Mikro Kecil Dan Menengah Di Kota Padang. JEBI (Jurnal Ekonomi Dan Bisnis Islam), 3(2), 237. https://doi.org/10.15548/jebi.v3i2.182

10. Husni Awali, Farida Rohmah (2020). "Urgensi Pemanfaatan E-Marketing Pada Keberlangsungan UMKM di Kota Pekalongan di Tengah Dampak Covid-19”. BALANCA: Jurnal Ekonomi dan Bisnis Islam Volume 2 No. 1 (1-14).

11. Kemp, S. (2020, August 10). Retrieved August 10, 2020, from http://wearesocial.com/blog/2020/08/digitalsoutheast-asia-2020

12. Kemenkop-UKM. (2020). Menkop dan UKM Paparkan Skema Pemulihan Ekonomi KUKM di Masa dan Pasca COVID-19. Retrieved from Http://Www.Depkop.Go.Id/Read/MenkopDan-Ukm-Paparkan-Skema-PemulihanEkonomi-Kumkm-Di-Masa-Dan-PascaCovid-19.

13. Kotler, P. and Keller, K. 2009. Marketing management.13th ed. Upper Saddle River.

14. Kotler, Philip, dan Gary Armstrong 2015. Prinsip-prinsip Pemasaran. Edisi 13. Jilid 1. Erlangga : Jakarta.
15. Kotler and Keller. 2016. Marketing Management. , Boston, Pearson Education.

16. Laudon, K. C., \& Traver, C. G. (2012). Ecommerce 2012 : Business, Technology, Society -8/E. Harlow: Pearson Education.

17. Lawrence, Elaine and Friends. (2011), Internet Commerce, Digital Model for Business, John Willey and Son, Indiana USA.

18. McCarthy. 2013. Basic Marketing, 16 th edition. New York: Mc Graw-Hill.

19. Novita Nurul Islami, Sri Wahyuni, Tiara (2020), "The Effect of Digital Marketing on Organizational Performance Through Intellectual Capital and Perceived Quality in Micro, Small and Medium Enterprises". Jurnal Organisasi dan Manajemen Volume 16 No. 1 (59-70) DOI : 10.33830/jom.v16i1.718.2020.

20. Rachmat Slamet, Bilpen Nainggolan et, all (2016). "Strategi Pengembangan UKM Digital Dalam Menghadapi Pasar Bebas". Jurnal Manajemen Indonesia Vol.16 - No.2.

21. Siregar, Sofyan. (2013). Metode Penelitian Kuantitatif. Jakarta : Prenadamedia Group.

22. Situmorang. (2010). Data Penelitian: Menggunakan Program SPSS. Medan: USU Press.

23. Soetjipto, H. N. (2020). Ketahanan UMKM Jawa Timur Melintasi Pandemi COVID-19.

24. Sinulingga, Sukaria. (2011). Metode Penelitian. Medan: USU Press.

25. Sugiyono. 2014. Metode Penelitian Kuantitatif Kualitatif dan R\&D.Bandung: Alfabeta.

26. Supriadi, C. (2016, November 16). Retrieved February 18, 2017, from http://www.marketing.co.id: http://www.marketing.co.id/dukungwirausaha-wanita-lewat-aplikasi-dbsbusinessclass/

27. Sugiyono. (2009). Metode penelitian bisnis: pen-dekatan kuantitatif, kualitatif, dan R \& D (Cetakan 14). Bandung: Alfabeta.

28. Stelzner, M.A. (2012). How Marketers Are Using Social Media to Grow Their Business. Social Media Marketing Industry Report.

29. Swastha. 2013. Manajemen PemasaranAnalisis Perilaku Konsumen, Yogyakarta : BPFE.

30. Tjiptono, 2015, Pemasaran Strategis, edisi terbaru, cetakan ketiga, Penerbit Andi, Yogyakarta. 
Ikhsan Al Zuhri et.al. Digital marketing implementation effectiveness analysis in improving the marketing performance of small and medium enterprises managed by LINKS USU.

31. Utomo, R. M. (2016, October 20). http://m.metrotvnews.com/teknologi/newsteknologi/. Retrieved February 17, 2017, from metrotvnews.com: http://m.metrotvnews.com/teknologi/newsteknologi/GNGyEMrk-pemanfaatan-digitalmarketing-di-indonesia-masih-minim

32. Willy Andrian Prabowo (2018), "Pengaruh Digital Marketing Terhadap Organizational Performance dengan Intellectual Capital dan Perceived Quality Sebagai Variabel Intervening Pada Industri Hotel Bintang Tiga di Jawa Timur". Jurnal Manajemen Pemasaran, Vol 12 No. 2. eISSN 2597-615X

33. Kim, E. Y., \& Kim, Y. (2011). Predicting online purchase intentions for clothing products null. European Journal of Marketing, 38(7), 883-897. http://doi.org/10.1108/03090560410539302

34. Novita Nurul Islami, Sri Wahyuni, Tiara (2020), "The Effect of Digital Marketing on Organizational Performance Through Intellectual Capital and Perceived Quality in Micro, Small and Medium Enterprises". Jurnal Organisasi dan Manajemen Volume 16 No. 1 (59-70) DOI : 10.33830/jom.v16i1.718.2020.

35. Evaggelia, F. (2015). Intellectual Capital \& Organiza-tional Advantage: an economic approach to its valuation and measurement. International Journal of Information, Business \& Management, 7(1), 36-57.

36. Garvin, David A. (1984). "What Does 'Product Quality' Really Mean?" MIT Sloan Management Review. 26(1).

37. Kim, E. Y., \& Kim, Y. (2011). Predicting online pur-chase intentions for clothing productsnull.European Journal of Marketing, 38(7), 883-897. http://doi.org/10.1108/03090560410539302

38. Aaker, D. (2003), "The power of the branded differentiatior", Sloan Management Review, Fall, pp. 83-87.

39. Ari Susanti, Budi Istiyanto, dan Muhammad Jalari (2020). "SMEs Strategy at Covid-19
Pandemic". KANGMAS: Karya Ilmiah Pengabdian Masyarakat, Vol.1 No.2. eISSN: 2722-2004.

40. Rachmat Slamet, Bilpen Nainggolan et, all (2016). "Strategi Pengembangan UKM Digital Dalam Menghadapi Pasar Bebas". Jurnal Manajemen Indonesia Vol.16 - No.2.

41. Andi Amri (2020). "Dampak Covid-19 Terhadap UKM di Indonesia". Jurnal Brand, Volume 2 No. 1. e-ISSN: 2715-4920

42. Husni Awali, Farida Rohmah (2020). "Urgensi Pemanfaatan E-Marketing Pada Keberlangsungan UMKM di Kota Pekalongan di Tengah Dampak Covid-19”. BALANCA: Jurnal Ekonomi dan Bisnis Islam Volume 2 No. 1 (1-14).

43. Helmalia, H., \& Afrinawati, A. (2018). Pengaruh E-Commerce Terhadap Peningkatan Pendapatan Usaha Mikro Kecil Dan Menengah Di Kota Padang. JEBI (Jurnal Ekonomi Dan Bisnis Islam), 3(2), 237. https://doi.org/10.15548/jebi.v3i2.182

44. Chaffey, Dave., Mayer, Richard., Johnston, Kevin., Ellis, Chadwick Fiona. (2000): Internet Marketing, London, Prentice Hall.

45. Stelzner, M.A. (2012). How Marketers Are Using Social Media to Grow Their Business. Social Media Marketing Industry Report.

46. Hanum, A. N., \& Sinarasri, A. (2017). Analisis faktor-faktor yang mempengaruhi adopsi e commerce dan pengaruhnya terhadap kinerja umkm (studi kasus umkm di wilayah kota semarang). Maksimum, Vol. 1(No. 1), 1-15.

How to cite this article: Ikhsan Al Zuhri, Sinulingga S, Iskandarini. Digital marketing implementation effectiveness analysis in improving the marketing performance of small and medium enterprises managed by LINKS USU. International Journal of Research and Review. 2021; 8(9): 488-496. DOI: https://doi. org/10.52403/ijrr.20210962 